\title{
CONTRAST DESCRIPTION OF JAPANESE AND CHINESE VERBAL COMMUNICATIVE BEHAVIOR
}

\author{
Nadira Tashmurzaevna Khalmurzaeva \\ Senior Researcher, Tashkent State University Of Oriental Studies, Uzbekistan
}

\section{ABSTRACT}

The article is devoted to the description of a contrast of Japanese and Chinese verbal communicative behavior. The study of this problemconsiders the process of verbal communicative behavior of Japanese people, which has a number of striking features that distinguish it from Chinese verbal communicative behavior.

The analysis suggests the difference and similarity of the rules of speech etiquette Japanese andChinese.

KEYWORDS: - Culture, Verbal behavior of communication, japanese, chinese, etiquette.

\section{INTRODUCTION}

In the course of the historical development of a nation, its experience is consolidated in the traditions, customs, habits of people, as well as in the norms of behavior, the way of reacting to the environment, in actions and in various standard situations.

Politeness represents a category of communicative consciousness and a reflection of the national mentality. It is the backbone that regulates the communicative behavior of people. Knowing the national characteristics of this category provides the key to understanding many of the features of the communicative behavior of any nation.

The communicative behavior of the people is a component of their national culture. The underlying reason for differences in communication behavior is the type of culture to which the interlocutors belong. "Culture - creates special forms of behavior, it modifies the activity of human mental functions." Ignoring those makes communication difficult and gives rise to numerous stereotypes.

J. Leach wrote about the generally accepted view of Chinese and Japanese people as being very polite in comparison with Europeans, Russians and Poles as being impolite $[1$, p.51]. J. Thomas notes the existence of stereotypes about rude Russians and Germans, obsequious Indians and Japanese, insincere Americans and arrogant British [2, p.91112].

Communication behavior describes not only polite, reference communication, but also real communication practice. Communication behavior includes speech etiquette as an integral part. In 
CURRENT RESEARCH JOURNAL OF PHILOLOGICAL SCIENCES 2(12):

170-176, December 2021

DOI: https://doi.org/10.37547/philological-crjps-02-12-33

ISSN 2767-3758

(C2021 Master Journals

Crossref do

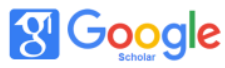

Accepted21 ${ }^{\text {th }}$ December, 2021 \& Published $26^{\text {th }}$ December, 2021

general, the national specificity of communicative behavior allows interpreting its description as a description of one of the aspects of the communicative aspect - the national linguistic personality [3].

The communicative culture of China is based on Confucian and Taoist ethical principles, according to which a wise person should live according to rituals and rules, live with dignity. He must follow the path of the golden mean, be balanced, restrain the expression of emotions, know his place, not violate the established order, not flaunt his dignity. These ethical principles still play a significant role in the life of the Chinese people. The first thing that catches your eye when communicating with the Japanese and Chinese is their politeness, courtesy, and respect for the interlocutor. They use etiquette formulas of greeting, farewell, and gratitude. They try not to offend the interlocutor, avoid being categorical in speech and explain the reasons for their actions at full-length. Both the Japanese and the Chinese try to contain their emotions. Even when it is unpleasant for them or bad, they do not show their frustration. The Japanese and Chinese are especially polite in relation to an older person or social status. Respect for elders is a characteristic feature of Japanese and Chinese culture. [4, p.201215].

If for Europeans old age is something that you can hardly be proud of, in the East, old age is associated with ideas of experience and wisdom. Old age is revered in the same way as kinship. A high degree of politeness, attention to the interlocutor, lack of pressure and categoricalness become effective means of communicative influence for the Japanese and Chinese. Chinese ideology, hieroglyphs, writing, painting, poetry and prose, conveying the subtlest states of the soul, teach people to think associatively. "An obvious feature of Chinese culture was the complexity of logic, abstraction and systematization, and the preference for feeling, specificity," says cultural scientist Kato Shuichi.

The verbal communication behavior of the Chinese has a number of striking features that distinguish it from the Japanese verbal communication behavior.

\section{RESEARCH MATERIALS AND ANALYSIS}

Communication behavior is a broader concept than speech etiquette. The latter is mainly associated with standard speech formulas in standard communicative situations, reflecting the category of politeness. In a way, communicative behavior describes the topic of communication, the perception of certain communicative actions by native speakers, the features of communication in large communicative areas such as family, team, foreigners, acquaintances, strangers and many others. [5].

Acquaintance: When meeting people, the Chinese often ask for their surname. When they get to know a person, they ask his age, this is a common ritual: "What is your precious surname?", "How old are you?" [6].

The question of age for the Chinese is very important, since the older the interlocutor, the more honor and respect he can count on. Uzbeks consider a person familiar only if they know his name and have talked to him. For the Chinese, an acquaintance is someone they know.

For the Japanese, acquaintance begins with an apology, since you distracted this person from the case. For example: 失礼ですが、山田さんでしょうか。Shitsureidesu ga ... Yamada-san deshou ka - Sorry, are you by any chance Yamada-san? 
CURRENT RESEARCH JOURNAL OF PHILOLOGICAL SCIENCES 2(12):

170-176, December 2021

DOI: https://doi.org/10.37547/philological-crjps-02-12-33

ISSN 2767-3758

(C)2021 Master Journals

Crossref d

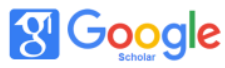

Accepted21 $1^{\text {th }}$ December, 2021 \& Published 26 $6^{\text {th }}$ December, 2021

Only then they bow down,present a business card and begin to introduce themselves: 私はタシケント国立東洋学大学の教師のモミノワ でござ日本語を教えつており々す。質問のす。質 問のすと質問のどうぞよろしくお願いいたします

Watakushiwatasikentokokuritsutoyogakudaigaku no kyoshi no Muminova de goderemasu. Nihongo wo oshieteorimasu. Ipoipo to sitsumonwaarimasu node mairimashita.

Doozoyoroshikuonegaiitashimasu.

I am a Japanese language teacher at TSUOSMuminova. I have different questions, so I came to you. I ask you to keep in touch with me in the future.

There is a presentation order in Japanese speech etiquette.

If it is necessary to introduce a man and a woman, usually the man is brought to the woman, or he himself comes up and says:

$$
\text { 恵子さん私は同じ会社の加藤ですが. . . }
$$

- Keiko-san watashi-waonajikaisha-no Kawai desuga.- Lady Keiko, I am Kawai, we work with you in the same company.

When introducing family members to strangers, they usually say:

山下さん、弟の陽一です。 - Yamashita-san otooto no Yoichi desu.- Yamashita-san, this is my younger brother, Yoichi.

Address: It is normal for the Chinese to address the interlocutor by name or position - teacher, instructor, director, chairman, etc. [7, p.134].

In Uzbek communication, treatment by profession or position is not considered polite, but rather is considered familiar. Relationship calls (grandmother, grandfather, aunt, uncle, etc.) in both Chinese and Japanese are respectful, speaking mostly as colloquial or vernacular.

The Japanese especially observe speech etiquette in various institutions, firms, and the service sector. Whatever relationship the Japanese have when they are in the service, they must behave as expected. Even close friends are supposed to be named officially in accordance with their status. For example, when talking with several interlocutors, American will address everyone in the same way. In Japan, a person is still assessed not as an individual, but only in terms of his social status. When applying to a company, it is more important than a profession and even a name or surname. The Japanese are more likely to refer to each other by position or kinship system, and rarely by name.

Of course, with all this, light bows must be made. In Japanese society, especially in an official setting, communicative behavior and speech etiquette are quite regulated, and the success or failure of business communication largely depends on their knowledge.

Apology: The Chinese do not apologize for minor violations. Qing yuan liang - Please forgive!

It is customary for the Japanese to apologize for the smallest concerns. This is the rule of polite communication. [8, p.201-215].

The Japanese apologize to friends and family, this is necessary. For the Chinese, it is not necessary to apologize to close friends and family.

The thought of humiliating oneself in speech and elevating the interlocutor does not leave the speaking Japanese. Therefore, according to the rules of etiquette, the Japanese should always thank 
CURRENT RESEARCH JOURNAL OF PHILOLOGICAL SCIENCES 2(12):

170-176, December 2021

DOI: https://doi.org/10.37547/philological-crjps-02-12-33

ISSN 2767-3758

(C)2021 Master Journals

Crossref do

gil Google

Accepted21 $1^{\text {th }}$ December, 2021 \& Published $26^{\text {th }}$ December, 2021

everyone and apologize. There are also many forms and degrees of apology in Japanese. Among them, the most common are すみません - sumimasen, ごめんなさい -gommennasai, しつれいします shitsureishimas, お許しください -yurushi-kudasai, 申し訳ありません-moushiwakearimasen, 大変失礼いたしました、 and others. They all mean "Sorry", "I apologize". The answer to the apology can be "doo itashimashite-Not at all" [9, p.71-89].

As a rule, expressions of apology are used without regard to the position of the interlocutor. Wherever one goes, the first thing to say is: ごめんください gomenkudasai "Sorry, please." The Japanese always apologize first, even if they are not guilty of anything. Moreover, they are in a hurry to apologize so that they are not outstripped. An employee in a company, service sector, i.e. wherever there is a two-way relationship (seller - buyer, service personnel - customer and others), no matter what happens, even if someone stepped on his foot, he must apologize first of all, saying "gomennasai sorry". According to the Japanese way of thinking, this is usually interpreted as follows: I am an inattentive person and because of me an oversight has turned out (for example, I was standing wrong, did not move, did not notice something, etc.). Thus, there is always a new reason to ask for forgiveness, without waiting for others to do it. There is something similar in Uzbek etiquette, when a polite person in a certain situation says: "If there was something wrong, forgive me, please!"

In formal situations, the following expressions are used when apologizing:こちらでの手違いで、お手数をおけし ました。 - Because of our oversight, you had to be disturbed.

Gratitude: The Chinese do not thank for insignificant services, usually they do not thank family and close friends. Gratitude for a minor service the Japanese have a rule of polite communication. A treat, a gift, and increased attention in Japanese communication can complement gratitude, but cannot completely replace its verbal expression, as in the Chinese. For example: Wo zhen duo xieni le. - I am very grateful to you.

Forms and degrees of expressing gratitude, as well as apologies, are the most commonly used in Japanese speech etiquette. In Japanese, the common word "thank you" has a wide variety of connotations depending on the social or official status of the interlocutor, as well as on the nature and service or attention for which gratitude is expressed. The most common expressions are "ありがとう - arigatou", "ありがとうございます arigato gozaimasu", more recently "どうも doomo".

Meeting, greeting: When greeting, the Chinese have an obligatory smile. For Uzbeks, a smile is not required when greeting, its absence does not mean bad behaviour towards the interlocutor. Greetings from a friend, relative, or colleague are mandatory in Uzbek communication, but not in Chinese. The Uzbek greeting should be carried out with a generally accepted stable verbal complex. Replacing the common greeting by the Chinese with a formula such as "Ah, have you come yet?", "Oh, are you reading?" etc. [10, p. 201-215] are considered to be impolite, since it is believed that the interlocutor did not greet in this case. For the Chinese, this is a form of greeting a friend. The Chinese, in comparison with the Uzbeks, are very restrained and have little emotional greetings to their relatives and close friends, this is the norm of Chinese speech etiquette; Restraint in greeting relatives and close friends among Uzbeks is considered a sign of bad behavior, a manifestation of impoliteness.

All of these greetings should be spoken with dignity 
CURRENT RESEARCH JOURNAL OF PHILOLOGICAL SCIENCES 2(12):

170-176, December 2021

DOI: https://doi.org/10.37547/philological-crjps-02-12-33

ISSN 2767-3758

(C)2021 Master Journals

\section{Crossref do) 81 Google}

Accepted21 ${ }^{\text {th }}$ December, 2021 \& Published $26^{\text {th }}$ December, 2021

and respect. It is not necessary to allow familiarity and go over the norms of etiquette. You should be careful and act according to the situation. The greetings that people exchange when they meet should be followed in a strictly defined order. It should always be borne in mind the politeness, age and position of the interlocutor. In general, Japanese speech etiquette is characterized by laconicism, the traditional beginning of a conversation, but greetings are quite ceremonious and lengthy. For instance, it is completely unusual from the point of view of European etiquette that a Japanese, having met with a friend, first of all begins to thank him for the services and favors that were provided to these acquaintances in the past, and sometimes after quite a long time, besides, they were quite small services and favors. Sometimes the Japanese are grateful for what happened 2-3 years ago, although these were mere trifles.

Except forおはようございます - ohayo gozaimasu "good morning", 今日は- konnichiwa "hello",こんばんは -konbanwa "good evening", they also sayご機嫌いかがですか- gokigenikagadesu ka “how are you”, はじめまして - hajimemashite"let me introduce myself”, はじめお目にかかりますー hajimeome-nikakarimasu"glad to meet you".When it's time to say goodbye, they sayさよなら sayonara "goodbye",ご機嫌よ- go kigenyo "bless you",ではまた -dewamata "well, bye!"

Telephone communication: The Chinese mainly use the telephone for purely business, informational purposes. Telephone communication has much more varied functions in Japan than in China. In particular, it is used for purely personal, nonbusiness conversations. In written communication, the Chinese often indicate the position or relationship of the addressee in the address [11, p.91].
The Japanese believe that talking on the phone is the hallmark of a company, institution, trade enterprise, even family and the house in which you live. It is believed that a lot depends on the telephone conversation in trade and other negotiations. If, in a personal conversation, some part of the manifestation of politeness can be taken over by bowing, smiling, gestures, etc., then during a telephone conversation, speech etiquette itself acquires exceptional importance [12].

The system of etiquette forms in the speech of the Japanese is particularly complex and reflects the social structure of Japanese society, in which there are still survivals of the once prevailing feudalpatriarchal relations. The complexity of all this is aggravated by the fact that social relations between members of society are transmitted not only lexically, but also grammatically. Moreover, this is reflected in the structure of the sentence being constructed.

As a matter of courtesy, the Japanese do not direct the conversation or try to keep it going. In conversation, they do not seek to dominate or persuade. They do not utter long rants or free statements, however, in the company of friends and well-known people, the Japanese are willing to talk. The Japanese are not specific. There is a subtext in any statement. Sometimes the whole meaning of what is said can only be felt in context. All this creates a sense of blurry speech, and Japanese polite speech contributes to this. Hence the abundance of non-categorical forms of expression. This is a manifestation of one of the basic principles of Japanese behavior - in no case to interfere in other people's affairs [13, p.112].

\section{Conclusion}

Thus, the following conclusions can be drawn regarding the communicative behavior of the 
CURRENT RESEARCH JOURNAL OF PHILOLOGICAL SCIENCES 2(12):

170-176, December 2021

DOI: https://doi.org/10.37547/philological-crjps-02-12-33

ISSN 2767-3758

(C2021 Master Journals

Crossref do

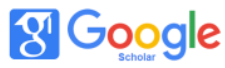

Accepted21 ${ }^{\text {th }}$ December, 2021 \& Published $26^{\text {th }}$ December, 2021

Japanese and Chinese. In general, the Chinese and Japanese demonstrate a fairly high speech culture. Their culture differs from European culture and is based on a centuries-old tradition. Similar characteristic features of the speech behavior of the Japanese and the Chinese are a high degree of politeness, lack of categoricality and restraint in the expression of emotions. Their verbal behavior is entirely subordinated to the task of providing maximum attention to the interlocutor, showing courtesy to him, creating a good mood inside him. They are also characterized by moderation in everything, including in speech behavior.

In a distinctive national feature of the communicative behavior of the Chinese it is important to take into account their mentality. In addition, it is important not to demand from them, for example, a dispute on an equal footing with an elder in age or social status, a story about personal problems and feelings, and not to seek a direct answer where the Chinese prefer indirect answers.

A distinctive national feature of the communicative behavior of the Japanese is in their unwillingness to stand out or be an exception. Expressing your thoughts vaguely is a characteristic of the Japanese. They are wary of clear-cut forms of expression, as the Japanese feel very connected by a word and therefore are afraid to say something definite.

Moreover, it is necessary to highlight that there are much more forms and degrees of apology in Japanese communicative speech etiquette than in Chinese speech etiquette.

\section{REFERENCES}

1. Leech, Geoffrey N. Principles of pragmatics. London and New York: Longman, 1983.

2. Thomas, Jenny. Cross-cultural pragmatic failure // Applied Linguistics, 4.- 1983.-Pp.
91-112.

3. Khalmurzaeva, N. T., Omonov, Q. S., Rikhsieva, G. S., \&Mirzakhmedova, K. V. (2021). SPECIFICITY OF THE ACTION OF SILENCE IN JAPANESE COMMUNICATION CULTURE. CURRENT RESEARCH JOURNAL OF PHILOLOGICAL SCIENCES (2767-3758), 2(08), 50-55.

4. Mirzakhmedova, K. V. (2021). Comparative Analysis of General Words-Terms In Persian and Uzbek Languages. Psychology and Education Journal, 58(1), 1050-1056.

5. Омонов, К. Ш. (2019). Stereotype phrases and their place in providing formality to the text. Молодойученый, (28), 259-261.

6. Hulkar, M. (2019). INTERACTIVE METHODS OF PEDAGOGICAL PROGRAMS IN TRAINING Oriental Languages. Uzbekistan Journal of Oriental Studies, 1(2), 146-155.

7. Nasirova, S. A., Hashimova, S. A., \&Rikhsieva, G. S. (2021). THE INFLUENCE OF THE POLITICAL SYSTEM OF CHINA ON THE FORMATION OF SOCIAL AND POLITICAL TERMINOLOGY. Journal of Central Asian Social Studies, 2(04), 10-17.

8. Mirzakhmedova, H. V., Omonov, K. S., \&Khalmurzaeva, N. T. (2021). METHODS OF IMPROVING LANGUAGE SKILLS USING MEDIA SOFTWARE. Journal of Central Asian Social Studies, 2(03), 47-55

9. Hashimova, S. A., \&Nasirova, S. A. (2021). FEATURES OF FORMING OF ANIMATED NOUNS WITH THE AFFIXES IN MODERN CHINESE LANGUAGE. Journal of Central Asian Social Studies, 2(04), 1-10.

10. Nasirova, S. A. (2020). CONCEPTS OF 中国梦想" CHINESE DREAM" AND 类命运共同" COMMUNITY OF THE ONE FATE OF HUMANITY"-A LINGUISTIC AREA. Journal of Central Asian Social Studies, 1(01), 05-14.

11. Халмурзаева, Н. Т. (2020). ТИПОЛОГИя ЯПОНСКОГО
КОММУНИКАТИВНО- 
CURRENT RESEARCH JOURNAL OF PHILOLOGICAL SCIENCES 2(12):

170-176, December 2021

DOI: https://doi.org/10.37547/philological-crjps-02-12-33

ISSN 2767-3758

(C)2021 Master Journals

Crossief do) 810 Google

Accepted21 ${ }^{\text {th }}$ December, 2021 \& Published $26^{\text {th }}$ December, 2021

ДЕЛОВОГО ЭТИКЕТА. Вестникнауки и образования, (14-2 (92)).

12. Хашимова, С. (2019). On some features of teaching foreign language for students of non-philological areas at the initial stage. ЕвразийскоеНаучноеОбъединение, (1-6), 334-338.

13. Khalmurzaeva, N. T. (2020). Peculiarities of intercultural understanding in Uzbek and japanese verbal communication. ACADEMICIA: An International Multidisciplinary Research Journal, 10(11), 1473-1481.

14. Omonov, Q. S., Rikhsieva, G. S., \&Khalmurzaeva, N. T. (2021). THE ORIGIN OF AN OFFICIAL TURKIC STYLE AND ITS PLACE IN THE DEVELOPMENT OF A WRITTEN LITERARY LANGUAGE. CURRENT RESEARCH JOURNAL OF PHILOLOGICAL SCIENCES (2767-3758), 2(08), 45-49.

15. Mirzaxmedova, H. (2020). TERMS MADE FROM THE ORIGINAL IRANIAN VOCABULARY IN PERSIAN. Philology Matters, 2020(1), 137-145.

16. Khalmurzaeva, N. T. (2019). СПОСОБЫ КЛАССИФИКАЦИИ ВЕРБАЛЬНЫХ ФОРМ КАТЕГОРИИ ВЕЖЛИВОСТИ В ЯПОНСКОМ ЯЗЫКЕ. Theoretical \& Applied Science, (12), 27-33. 